\title{
MUTANTS IN THE BIOSYNTHESIS OF ISOLEUCINE IN A NON-MATING, NON-SPORULATING BREWING STRAIN OF SACCHAROMYCES CARLSBERGENSIS
}

\author{
by \\ MORTEN C. KIELLAND-BRANDT, JENS G. LITSKE PETERSEN \\ and JØRN DALGAARD MIKKELSEN \\ Department of Physiology, Carlsberg Laboratory, \\ Gamle Carlsberg Vej 10, DK-2500 Copenhagen Valby
}

Keywords: Dominant mutants, thiaisoleucine resistance, threonine deaminase, fusel alcohols

\begin{abstract}
Mutants resistant to 2-amino-3-(methylthio)butanoic acid (thiaisoleucine) were selected from a non-mating, nonsporulating brewing strain of Saccharomyces carlsbergensis after treatment with $\mathrm{N}$-methyl-N'-nitro-Nnitrosoguanidine. One closer studied mutant, C77-T70 had a threonine deaminase activity which was less sensitive to $\mathrm{L}$-isoleucine than that of the parent strain. The inhibition with varying concentrations of $L$-isoleucine showed that part of the activity was as sensitive as that of the parent strain, suggesting that the mutant is heterozygous for a dominant change in the structural gene for threonine deaminase. Of twelve mutants selected on $25 \mathrm{~mm}$-thiaisoleucine all are believed to have undergone a change similar to that of C77-T70, since their threonine deaminase activity was partly resistant to $1 \mathrm{mM}$-L-isoleucine like that of C77-T70. Four such mutants were compared to the parent strain for the production of fusel alcohols during aerobic growth in minimal medium. The synthesis of 2-methyl-1-butanol (D-amyl alcohol) was 2-5 times higher in the mutants than in the parent strain, while the syntheses in the mutants of 3-methyl-1-butanol (isoamyl alcohol) and 2-methyl-1propanol (isobutanol) were similar or slightly reduced compared to the level found in the parent strain.
\end{abstract}

\section{INTRODUCTION}

One of the major obstacles to the crossbreeding of brewing strains of yeast is that they are usually impaired in sporulation and/or mating. Also attempts to do breeding on single brewing strains by mutation are usually met with severe difficulties, since most of the strains are diploid or polyploid.
In a situation like that, one possibility is to isolate dominant mutants. Since dominant mutations are much more rare than recessive ones, this approach is no general solution to the breeding problem, but could be of value in special cases.

In Saccharomyces cerevisiae one class of mutants resistant to the amino acid analogue

Abbreviations: GLC = gas-liquid chromatography, YPG $=$ yeast extract peptone glycerol, YPD $=$ yeast extract peptone dextrose 


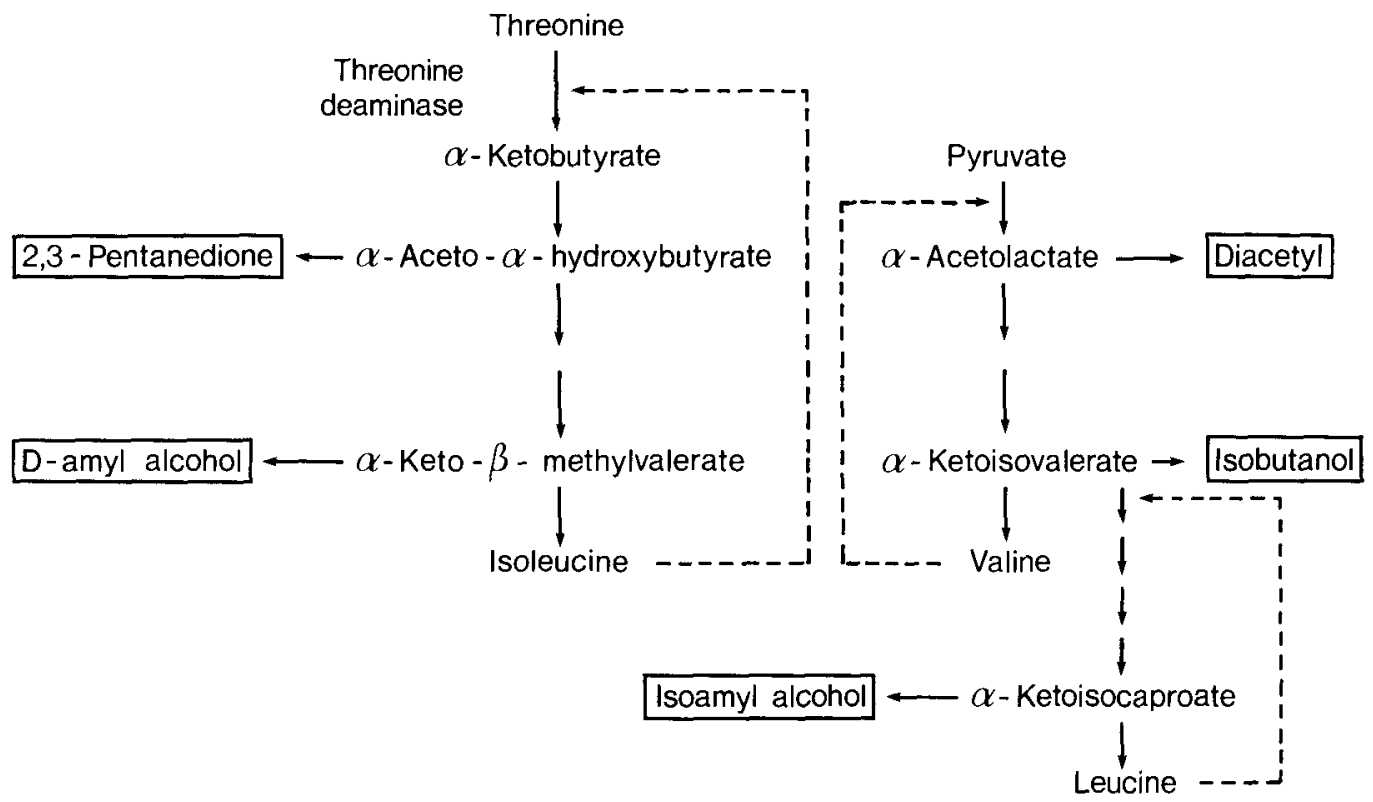

Figure 1. Several important flavor/off-flavor compounds in beer are formed as side products in the biosyntheses of isoleucine, valine and leucine. Their commonly used names are shown and their systematic names are: 2, 3pentanedione, butanedione (diacetyl), D-2-methyl-1-butanol (D-amyl alcohol), 2-methyl-1-propanol (isobutanol), 3-methyl-1-butanol (isoamyl alcohol). Broken arrows indicate feed-back inhibition of enzyme reactions.

thiaisoleucine have a threonine deaminase (EC 4.2.1.16) which is altered to have activity in the presence of high concentrations of L-isoleucine (1). This leads to overproduction of L-isoleucine, which may be the cause for resistance of the cells to thiaisoleucine. Such mutants would be expected to be dominant, since the mutant enzyme should be able to cause overproduction also in the presence of wild type enzyme.

The biosyntheses of isoleucine, valine and leucine have special interest for the brewer, since several flavor/off-flavor compounds in beer are formed from intermediates in the biosyntheses of these amino acids (Figure 1). Threonine deaminase has particular importance, since it may have a regulatory role for the synthesis of other enzymes in the pathways.

This paper describes the isolation from a nonmating, non-sporulating brewing strain of $\mathrm{S}$. carlsbergensis of mutants resistant to thiaisoleucine. Some characterization of the mutants was carried out, especially regarding their threonine deaminase.

\section{MATERIALS AND METHODS}

\subsection{Thiaisoleucine}

The systematic name of this compound, $\mathrm{CH}_{3} \mathrm{SCH}\left(\mathrm{CH}_{3}\right) \mathrm{CH}\left(\mathrm{NH}_{2}\right) \mathrm{COOH}$, is 2-amino-3(methylthio)butanoic acid, but it is usually referred to as thiaisoleucine, since it may be regarded as isoleucine in which the $\mathrm{CH}_{2}$ group has been substituted by a sulfur atom.

The only description of its synthesis is by McCord et al. (11). Since the synthesis starts with symmetric compounds, the product must be a racemic mixture, but it has not been determined whether it is the DL-allo-mixture, the DL-threo-mixture or a mixture of all four forms. Biologically, thiaisoleucine seems to act as an analogue of both L-isoleucine (17) and Lthreonine (6).

A small amount of thiaisoleucine was obtained commercially (Sigma no. T-6259, DL-4thiaisoleucine). However, because of the amounts needed, it was also synthesized in this laboratory as described below. In a quantitative test of its inhibitory effect on threonine deamin- 
ase, the synthesized product had an activity indistinguishable from that of the commercial preparation.

The following procedure is essentially that of McCord et al. (11) with the exception that 2phenyl-4-ethylidene-5-oxazolone was synthesized by a slight modification of a more recent, better yielding procedure (13) than that of CARTER et al. (5).

Sodium acetate (88 g, Merck no. 6268) was dried at $160^{\circ} \mathrm{C}$ for 16 hours, cooled, mixed with $250 \mathrm{~g}$ of hippuric acid (Merck no. 296) and placed in a two liter flask. Redistilled acetic anhydride $(500 \mathrm{ml})$ was added and the flask was placed in ice and equipped with a reflux condenser cooled at $2^{\circ} \mathrm{C}$. With occasional shaking, acetaldehyde was distilled into the mixture through a second, oblique condenser by heating a mixture of $300 \mathrm{ml}$ paraldehyde (Fluka no. 76260 ) and $3 \mathrm{ml}$ concentrated sulfuric acid until about $50 \mathrm{ml}$ were left. The reaction mixture was left at $25^{\circ} \mathrm{C}$ for 16 hours, heated with reflux for 2 hours and left at $25^{\circ} \mathrm{C}$ for 20 hours. Again $250 \mathrm{ml}$ of paraldehyde were converted to acetaldehyde and distilled into the mixture as described above, and the mixture was refluxed for $2 \frac{1}{2}$ hours, cooled and poured into 5 liters of cold water. The precipitate $(330 \mathrm{~g}$ pressed wet weight) was washed with water and $84 \mathrm{~g}$ of orange, partially pure 2-phenyl-4-ethylidene-5oxazolone were recovered by one crystallization from $400 \mathrm{ml}$ of methanol and dessication over sulfuric acid. Mp. $86-92^{\circ} \mathrm{C}$ (literature $93-96^{\circ} \mathrm{C}$ (13) and $\left.95-96^{\circ} \mathrm{C}(5)\right)$.

Fifty grams of this compound were treated with methanethiol (Fluka no. 67778) in the presence of sodium methoxide as described by McCond et al. (11), but scaled up. Fortynine grams of the reaction product melting at $72-$ $75^{\circ} \mathrm{C}$ were recovered by crystallization from ethanol at $-20^{\circ} \mathrm{C}$ in 16 hours. McCord et al. state this product to be 2-benzamido3-(methylthio)butanoic acid, but it might seem to be the methyl ester of the acid.

A small amount of this product was hydrolyzed to thiaisoleucine and the benzoic acid removed as described by McCord et al. (11). We could not get the thiaisoleucine hydrochloride to crystallize from the suspension in benzene described by MCCORD et al. Therefore, in a second preparation, instead of adding benzene to the oily acid residue containing the hydrochloride, this was diluted with distilled water, titrated to neutrality with sodium hydroxide and brought to dryness. From the amount of sodium hydroxide used, the percentage of sodium chloride in the powdered residue was calculated to be 35 . The rest was thiaisoleucine as judged from its biochemical activity being equal to that of the commercial product. The powder was used as thiaisoleucine correcting for its content of sodium chloride.

\subsection{Strains, media and growth of cultures}

The parental strain was a brewing strain of $\mathbf{S}$. carlsbergensis used in a previous study (7). With standard techniques, we have failed to observe mating and sporulation of this strain. Mutants were derived as described below. Media have been described $(7,9)$. Growth in liquid cultures was with shaking at $30^{\circ} \mathrm{C}$, unless stated otherwise.

\subsection{Isolation of mutants resistant to thia- isoleucine}

Treatment of cells with $0.7 \mu \mathrm{M}-\mathrm{N}$-methyl-N'nitro-N-nitrosoguanidine was as described (9). Then the cells were washed twice in $3 \mathrm{~mm}$ EDTA, pH 6.5, suspended and diluted in the same buffer, and different dilutions were plated directly onto minimal medium containing different concentrations of thiaisoleucine as will be indicated. Colonies were picked, single colonies reisolated and suspensions retested for resistance to thiaisoleucine on minimal plates with a paper strip containing $3 \mathrm{mg}$ of the drug placed perpendicularly onto the streaks of cells.

In the selection and retesting of thiaisoleucine resistant mutants residual growth of sensitive cells was often a problem, especially when cells had been densely seeded on a plate. Evidently sensitive cells help one another to overcome the action of the drug, whether this be due to metabolization of the drug, leakage of isoleucine, or some other mechanism. 


\subsection{Cell free extracts}

Cells were harvested and washed in cold 0.1 M-Tris- $\mathrm{HCl}, \mathrm{pH} 7.7$ by centrifugation. The pellet was suspended in three times its volume cold $25 \%(\mathrm{v} / \mathrm{v})$ glycerol, $1 \mathrm{~mm}$-EDTA, $10 \mathrm{~mm}$ dithiothreitol, $0.5 \mathrm{~m}$-Tris- $\mathrm{HCl}, \mathrm{pH} 7.7$ (buffer A). The suspension was mixed with an equal volume of glass beads (diameter $0.5 \mathrm{~mm}$ ) and agitated in a Braun-Melsungen MSK II homogenizer for 1 minute at 2,000 rpm with cooling. The homogenate was cleared by centrifugation in the Sorvall SS-34 rotor at $20,000 \times \mathrm{g}$ for 10 minutes at $0^{\circ} \mathrm{C}$ and the supernatant frozen and stored at $-70^{\circ} \mathrm{C}$.

\subsection{Permeabilization of cells with toluene}

The following is a modification of the procedure of MAGEE and Hereford (10). Cells were harvested and washed as above and $2 \cdot 10^{9}$ cells were suspended in $3.5 \mathrm{ml}$ buffer $\mathrm{A}+0.1$ mM-pyridoxal-5-phosphate on ice. Half a $\mathrm{ml}$ toluene was added and the mixture was agitated on a whirlimixer for 30 seconds and incubated at $30^{\circ} \mathrm{C}$ for 2 minutes. After cooling in ice the cells were pelleted at $27,000 \times \mathrm{g}$ for 5 minutes, suspended in $2 \mathrm{ml}$ buffer $\mathrm{A}$ and stored at $-70^{\circ} \mathrm{C}$.

\subsection{Enzyme assay}

The assay for threonine deaminase was carried out spectrophotometrically in $1 \mathrm{ml}$ samples at $23^{\circ} \mathrm{C}$ using the coupled assay described by DE ROBICHON-SzULMAJSTER and MaGeE (14). The sample was 5-30 $\mu 1$ of cell free extract or of toluene treated cells, as stated. Lthreonine was present at $25 \mathrm{~mm}$ unless otherwise stated.

\subsection{Extraction and gas-liquid chromatogra- phic (GLC) analysis of D-amyl alcohol, isoamyl alcohol and isobutanol from yeast cultures}

Cells were grown in $250 \mathrm{ml}$ synthetic minimal medium in a shaking water bath at $20^{\circ} \mathrm{C}$ to late exponential or early stationary phase. The cells were removed by centrifugation $(10,000 \times \mathrm{g}$ for 15 minutes $)$ and duplicate $50 \mathrm{ml}$ samples of supernatant medium extracted once with $2 \mathrm{ml}$ and four times with $1 \mathrm{ml}$ of redistilled chloroform. Extractions were done at $0^{\circ} \mathrm{C}$ in order to minimize evaporation of the alcohols. The 5 extracts from each of the two culture supernatant samples were combined and concentrated to $150-200 \mu \mathrm{l}$ by a stream of nitrogen. Two aliquots $(1-2 \mu 1)$ from each of the two combined extracts were then quantitated by GLC. The amounts of alcohols were taken as the means of the four determinations.

GLC analysis was performed with a HewlettPackard 5840A series gas chromatograph with a flame ionization detector. A coiled stainless steel column, $1520 \times 3.2 \mathrm{~mm}$, containing $0.2 \%$ Carbowax 1500 on Carbopack C 80/100-mesh (Supelco) was used. The following temperature program was employed: Isothermal at $80^{\circ} \mathrm{C}$ for 12 minutes, then an increase to $95^{\circ} \mathrm{C}$ with $3^{\circ} \mathrm{C} \cdot \mathrm{min}^{-1}$. The final temperature was maintained for 40 minutes. The peaks were identified using authentic standards (Merck no. 806031, 979 and 984).

In order to calculate the absolute amounts of D-amyl alcohol, isoamyl alcohol and isobutanol in the cell culture the gas chromatograph was calibrated according to the methods of NETTING and BARR (12). A series of injections of known volumes between 0.1 and $3.0 \mu \mathrm{l}$ of a standard solution containing $0.919 \mathrm{nmol} \cdot \mu \mathrm{l}^{-1}$ of 2 methyl-1-butanol was performed resulting in the calibration equation $\mathrm{IU} / \mathrm{E}=10689 \times \mathrm{N}+$ 117, where IU is the integrator units, $E$ the effective carbon number and $\mathrm{N}$ nmoles injected. From the data given by STERNBERG et al. (16) the effective carbon numbers of D-amyl alcohol, isoamyl alcohol and isobutanol were calculated to $4.4,4.4$ and 3.4 , respectively. The absolute amounts (nmoles) of the three alcohols could then be determined by inserting the IU values into the above equation.

Chloroform extraction of aqueous standard solutions containing known amounts of the three alcohols was almost $100 \%$ efficient for D-amyl alcohol and isoamyl alcohol. The extraction of isobutanol was less efficient (about 75\%), probably because the partition of isobutanol was less in favor of the organic phase. A portion of the alcohols was lost during concentration of the extracts. When two solutions of $5 \mathrm{ml}$ chloroform containing known amounts of the three alcohols were concentrated to 185 and $72 \mu 1$, the following recoveries were obtained: D-amyl 
alcohol 71.0 and $68.4 \%$, isoamyl alcohol 74.3 and $71.6 \%$, isobutanol 44.6 and $35.4 \%$. No corrections were made for losses during extraction or concentration of the extracts when calculating the total amounts present in the media.

\section{RESULTS}

\subsection{Thiaisoleucine resistant mutants}

Cells treated with $0.7 \mu \mathrm{M}-\mathrm{N}$-methyl-N'-nitro$\mathrm{N}$-nitrosoguanidine to a survival of $10 \%$ (27 minutes treatment) were washed and plated on minimal medium containing $25 \mathrm{~mm}$ - or $5 \mathrm{~mm}$ thiaisoleucine (own preparation) at different cell densities.

After 2 to 3 days at $30^{\circ} \mathrm{C}$ colonies began to appear on thiaisoleucine. We isolated the 31 largest colonies appearing on a $25 \mathrm{~mm}$-thiaisoleucine plate seeded with $4 \cdot 10^{7}$ cells. They were reisolated for single colonies on YPG plates and retested towards thiaisoleucine. Fourteen were found to be resistant, one was scored as sensitive like the parent strain, and the rest were intermediate or doubtful. Cells from the same mutagenized population were also plated on YPG medium and 20,000 colonies were replicated to minimal medium in search for auxotrophic mutants. None were found.

Four presumptive mutants were isolated in a previous experiment after a four times heavier mutagen treatment by selection on $5 \mathrm{~mm}$ thiaisoleucine (Sigma).

\subsection{Mutants have an altered threonine de- aminase}

The parent strain and the four presumptive mutants selected on $5 \mathrm{~mm}$-thiaisoleucine were grown on minimal medium with L-leucine ( 60 $\mathrm{mg} \cdot 1-1)$ and harvested in exponential phase $\left(<10^{7}\right.$ cells and buds per $\left.\mathrm{ml}\right)$. The threonine deaminase activities of extracts were determined with L-isoleucine present at different concentrations. The results for the parent strain and one mutant called C77-T70 are given in Figure 2. The three other mutants did not differ from the parent strain and were not further analysed. The data show that the threonine deaminase activity of the mutant is less sensitive to the inhibition by L-isoleucine than that of the parent strain. Our interpretation is that the mutation is in the

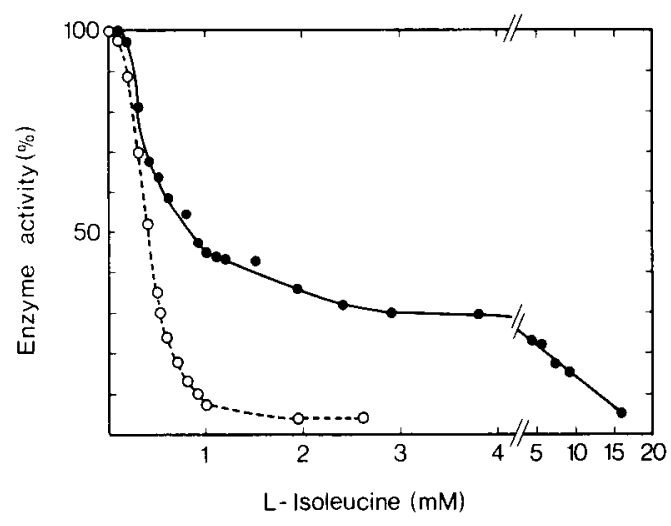

Figure 2. Inhibitory effect of L-isoleucine on the threonine deaminase activity of cell free extracts from a non-mating, non-sporulating brewers yeast $(\mathrm{O} \ldots \mathrm{O})$ and a mutant selected from it on $5 \mathrm{~mm}$ thiaisoleucine, $\mathrm{C} 77-\mathrm{T} 70(-)$. The specific activities without isoleucine were 156 and 131 nmoles per min per mg protein, respectively.

structural gene for threonine deaminase (in S. cerevisiae called $i l v l)$ and that the resistance to thiaisoleucine is due to an increased intracellular concentration of $\mathrm{L}$-isoleucine caused by the lower feed-back inhibition. The shapes of the curves have two notable features. First, the shoulders at $0.1 \mathrm{~mm}$ may be interpreted as cooperative binding of L-isoleucine, which seems comparable in the mutant and the parent. Secondly, the shape of the curve for the mutant is indicative of the enzyme activity consisting of (at least) two components one of which is as sensitive to Lisoleucine as the activity of the parent strain, whereas the rest is much more resistant. A likely interpretation is that the mutant contains one mutant allele coding for an L-isoleucine resistant enzyme and one or a few wild type alleles.

When the 14 retested mutants selected on 25 mM-thiaisoleucine were obtained, 12 of them were investigated for the action of $\mathrm{L}$-isoleucine on their threonine deaminase activity as follows. Cultures of the parent strain, the 12 new mutants and C77-T70 were grown on YPD to stationary phase, harvested, and treated with toluene (cf. Materials and Methods, 2.5). The threonine deaminase activity of the permeabilized cells was determined in the presence of 1 mM-L-isoleucine and compared to that found without L-isoleucine (Table I). The threonine 
Table I.

Twelve mutants selected on $\mathbf{2 5} \mathrm{mm}$-thiaisoleucine. All have a threonine deaminase activity changed to be less sensitive to $L$-isoleucine.

Strain No. of determinations

Threonine deaminase activity in the presence of $1 \mathrm{mM}$-L-isoleucine compared to isoleucine being absent (per cent, mean)

\begin{tabular}{llr}
\hline Parent strain & 5 & 5 \\
C77-T70 & 3 & 43 \\
$-\mathrm{T} 226$ & 2 & 64 \\
$-\mathrm{T} 227$ & 2 & 41 \\
$-\mathrm{T} 228$ & 2 & 55 \\
$-\mathrm{T} 230$ & 2 & 51 \\
$-\mathrm{T} 232$ & 3 & 35 \\
$-\mathrm{T} 233$ & 2 & 43 \\
$-\mathrm{T} 235$ & 2 & 48 \\
$-\mathrm{T} 236$ & 2 & 32 \\
$-\mathrm{T} 238$ & 2 & 46 \\
$-\mathrm{T} 251$ & 2 & 46 \\
$-\mathrm{T} 252$ & 2 & 45 \\
$-\mathrm{T} 254$ & 2 & 39 \\
\hline
\end{tabular}

deaminase of all the 12 new mutants was less sensitive to L-isoleucine than that of the parent strain.

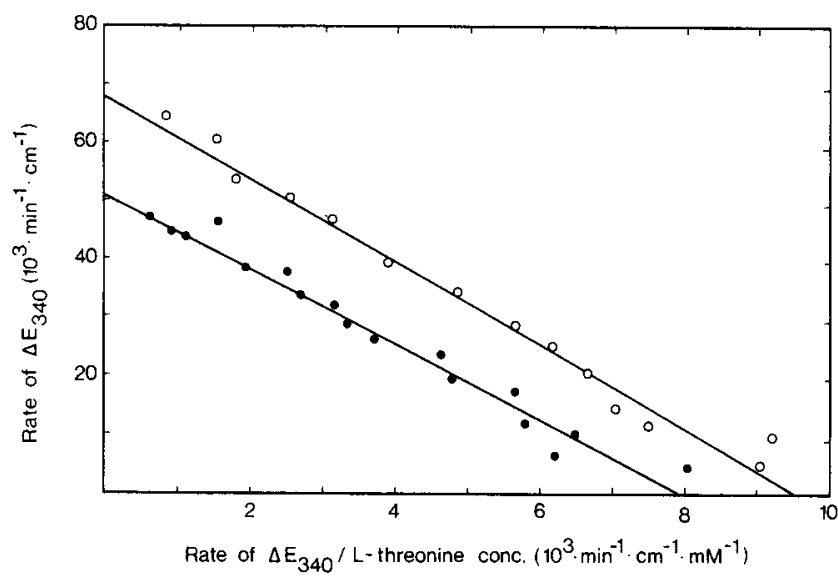

Figure 3. Determination of the apparent $\mathrm{K}_{\mathrm{m}}$ of threonine deaminase in the presence of $10 \mathrm{mM}-\mathrm{L}$ valine in extracts from the parent strain $(O)$ and the mutant $\mathrm{C} 77-\mathrm{T} 70(\bullet)$. The same extracts were used as for the experiment in Figure 2. Slopes $\left(-K_{m}\right)$ are $-7.11 \mathrm{~mm}(\mathrm{O})$ and $-6.40 \mathrm{~mm}(\bullet)$ found by regression analysis.

\subsection{Further characteristics of threonine de- aminase from $\mathrm{C} 77-\mathrm{T} 70$ and the parent strain}

Threonine deaminase of $\mathrm{S}$. cerevisiae is an allosteric enzyme, which interacts with L-valine and L-isoleucine in addition to its substrate and to which a simple $\mathrm{K}_{\mathrm{m}}$ can not be assigned. However, an apparent $K_{m}$ can be determined in the presence of $10 \mathrm{~mm}$-L-valine (14). Since the enzyme of $\mathrm{S}$. carlsbergensis is expected to be very similar, we chose the apparent $K_{m}$ in the presence of L-valine as another parameter to compare the enzyme activities in the two strains (Figure 3). The plots are linear within experimental error and lead to an apparent $\mathrm{K}_{\mathrm{m}}$ of 7.11 $\mathrm{mM}$ (standard error 0.28 ) and $6.40 \mathrm{~mm}$ (standard error 0.29) for parent strain and mutant, respectively. The two values are not significantly different $(0.05<\mathrm{P}<0.1)$.

As a further comparison between the threonine deaminase activities of C77-T70 and the parent strain, the specific activities of a few extracts were compared. No dramatic differences were found (Table II). We have not investigated whether the slightly lower value for the mutant is significant. For the parent strain, the somewhat higher value after growth in the presence of L-leucine was expected (3). The mutant seems to show the same effect. 
Table II.

Specific threonine deaminase activities of $\mathrm{C} 77-\mathrm{T} 70$ and the parent strain grown in minimal medium with or without L-leucine.

\begin{tabular}{llcc}
\hline Strain & $\begin{array}{c}\text { L-leucine present } \\
\left(60 \mathrm{mg} \cdot 1^{-1}\right)\end{array}$ & $\begin{array}{c}\text { Cell }+ \text { bud density } \\
\text { at harvest }\left(10^{6} \cdot \mathrm{ml}^{-1}\right)\end{array}$ & $\begin{array}{c}\text { Activity relative to total } \\
\text { amount of protein in extract } \\
\left(\mathrm{nmol}^{-1} \mathrm{~min}^{-1} \cdot \mathrm{mg}^{-1}\right)\end{array}$ \\
\hline Parent & No $^{\mathrm{a}}$ & 7.0 & 102 \\
& No & 7.0 & 91 \\
& No & 18 & 71 \\
C77-T70 & Yes & 7.8 & 156 \\
& No & 7.0 & 67 \\
\hline
\end{tabular}

a) Extract used in experiment in Figure 4.

b) Extract used in experiments in Figures 2 and 3

\subsection{Inhibition by thiaisoleucine of threonine deaminase of the parent strain}

The threonine deaminase activity of an extract of the parent strain was determined in the presence of different concentrations of thiaisoleucine (Figure 4). It was a less effective inhibitor than L-isoleucine on a molar basis and did not show the sigmoid pattern indicative of cooperative binding of the latter.

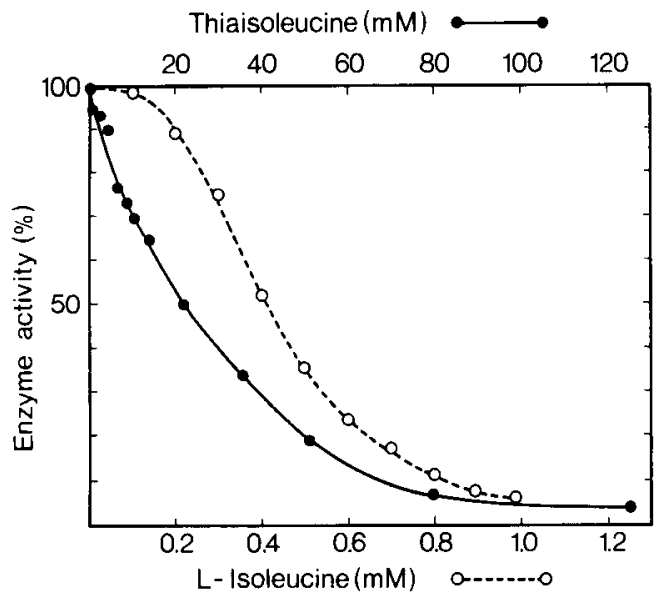

Figure 4. Inhibitory effect of thiaisoleucine (Sigma) on the threonine deaminase activity of a cell free extract from the parent strain. The effect of $L$ isoleucine is included for comparison. Half inhibition is at $23 \mathrm{~mm}$-thiaisoleucine and at $0.42 \mathrm{~mm}$-Lisoleucine.

\subsection{Formation of fusel alcohols}

The increased synthesis of L-isoleucine, which we believe takes place in the mutants, might be expected to cause an increased formation of $D$ amyl alcohol (cf. Figure 1).

The parent strain and four of the mutants presented in Table I were grown to different cell densities and the amounts of D-amyl alcohol, isoamyl alcohol and isobutanol in the culture medium were determined by GLC analysis. Because of the low amounts of these alcohols which are found with the growth conditions used (shaking in minimal medium), it was necessary to subject the culture supernatants to extractions with chloroform and determine the amounts of the alcohols in the chloroform phase after evaporation of most of the chloroform. Figure 5 illustrates the GLC patterns of two cultures of the parent strain grown to different cell densities, as well as a culture of mutant C77-T70. The results of the GLC analysis are given in Table III. From the results obtained with the parent strain and the mutant strain C77-T70 it appears that the concentrations of isobutanol and D-amyl alcohol in the culture medium increase with increasing cell density, while the concentration of isoamyl alcohol is more or less unchanged. Although this complicates a comparison between the strains, we wish to draw the main conclusion that the levels of $D$ amyl alcohol found in the mutant strains are increased 2- to 5-fold as compared to the parent 


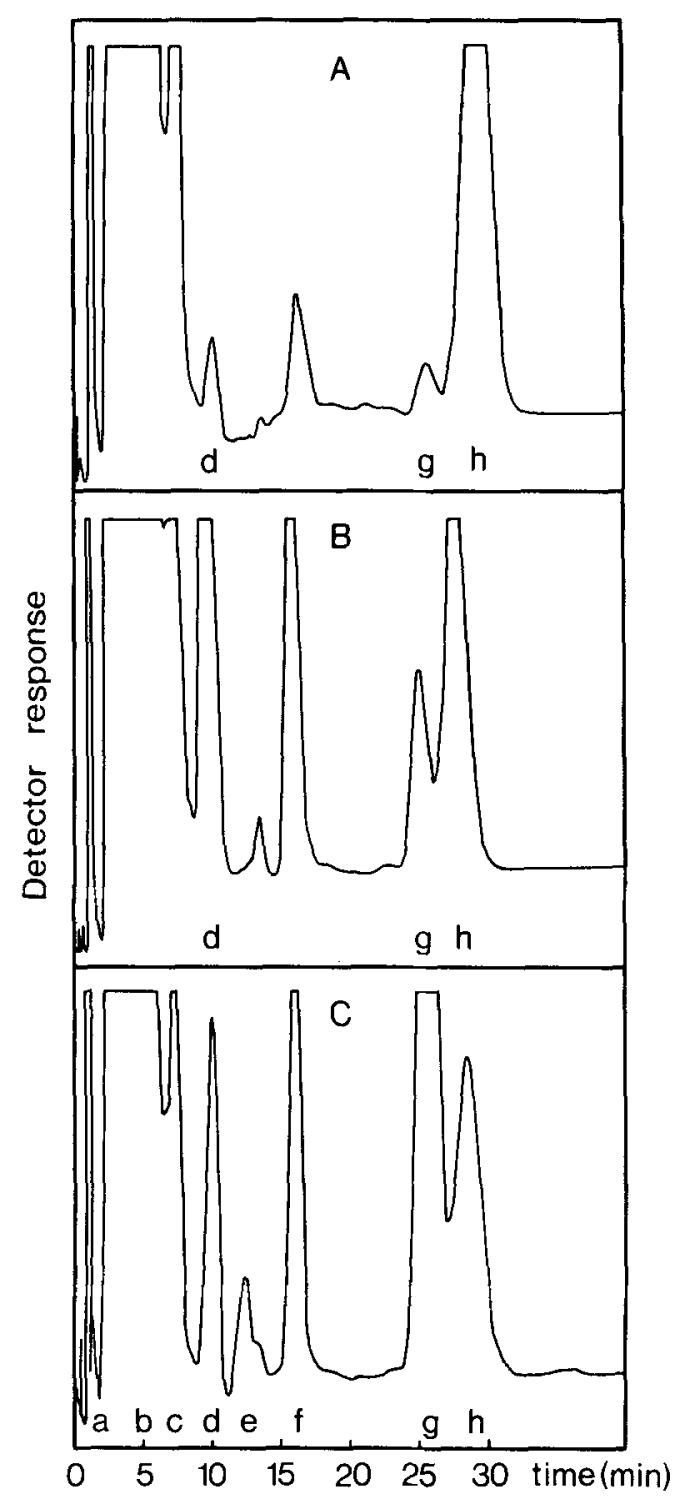

Figure 5. Gas-liquid chromatograms of D-amyl alcohol, isoamyl alcohol and isobutanol extracted from aerobic cultures in minimal medium. A, the parent strain grown to $5.0 \cdot 10^{6}$ cells $\cdot \mathrm{ml}^{-1}$ (exponential growth phase); B, parent strain, $9.1 \cdot 10^{6}$ cells $\cdot \mathrm{ml}^{-1}$ (early stationary phase); $\mathrm{C}$, mutant C77$\mathrm{T} 70,6.3 \cdot 10^{6}$ cells $\cdot \mathrm{ml}^{-1}$ (early stationary phase). Compound d, isobutanol; $\mathrm{g}$, D-amyl alcohol; $\mathrm{h}$, isoamyl alcohol; b, chloroform; $a, c, e$ and $f$ are unknown.

strain. The increased levels of D-amyl alcohol in the mutants are also evident when comparing the ratios of D-amyl alcohol to isoamyl alcohol.

\section{DISCUSSION}

We have selected mutants resistant to thiaisoleucine after mutagen treatment to a survival of $10 \%$ of a non-mating, non-sporulating brewing strain of S. carlsbergensis. This treatment did not give any auxotrophs among 20,000 colonies tested, consistent with the assumption that the strain is diploid or of higher ploidy. One thiaisoleucine resistant mutant, C77-T70, isolated early in this study, was investigated in more detail than the others. This mutant, as well as all tested mutants selected on $25 \mathrm{~mm}$-thiaisoleucine, had a threonine deaminase activity which was less sensitive to inhibition by L-isoleucine than was the activity of the parent strain. In this respect, these mutants are analogous to the two thiaisoleucine resistant mutants MAR33 and TIR-9 isolated by BETZ et al. (1) from haploid laboratory strains of $S$. cerevisiae. However, the inhibition curve of the enzyme activity of C77T70 (Figure 2) is different from that found by BETz et al. for their haploid mutants. First, we do not find a peak of activation of the enzyme at very low L-isoleucine concentrations, neither in C77-T70 nor in the parent strain; only a shoulder is seen. We have not investigated whether this is due to a small endogenous amount of L-isoleucine or L-valine in the crude extract, or whether it reflects a real difference between the enzymes of the brewing strain and the laboratory strains. Secondly, the curve for C77-T70 is indicative of the activity consisting of at least two components, one of which has a sensitivity to L-isoleucine similar to that of the parent strain, whereas the rest is more resistant. This behavior was expected, since we anticipated the thiaisoleucine resistant strains to be heterozygous in the structural gene for threonine deaminase for a dominant mutation responsible for the drug resistance. However, it is probably of no avail to analyse the curve for the question whether the brewing strain is diploid or has a higher ploidy. One reason is that the biosynthetic threonine deaminase - in $\mathbf{S}$. cerevisiae and all other organisms investigated - is a multimer and we do not know what behavior to expect from an enzyme molecule consisting of both mutant and wild type monomers.

We believe that the mutants are changed in the structural gene for threonine deaminase, but it should be kept in mind that this notion is based 
Table III.

Production of fusel alcohols during aerobic growth of 4 thiaisoleucine resistant mutants and their parent strain.

\begin{tabular}{|c|c|c|c|c|c|}
\hline \multirow[t]{2}{*}{ Strain } & \multirow{2}{*}{$\begin{array}{c}\text { Cell }+ \text { bud } \\
\text { density } \\
\left(10^{6} \cdot \mathrm{ml}^{-1}\right)\end{array}$} & \multicolumn{3}{|c|}{$\begin{array}{c}\text { Fusel alcohols recovered } \\
\text { ( } \mu \mathrm{g} \text { per liter growth medium) }\end{array}$} & \multirow{2}{*}{$\begin{array}{c}\text { Ratio }^{\mathrm{a}} \\
\text { D-amyl//soamyl }\end{array}$} \\
\hline & & Isobut-OH & D-amyl-OH & Isoamyl-OH & \\
\hline \multirow[t]{3}{*}{ Parent } & 4.4 & 2.8 & 11.2 & 192.8 & $0.058 \pm 0.012$ \\
\hline & 5.0 & 4.2 & 8.2 & 155.0 & $0.053 \pm 0.005$ \\
\hline & 9.1 & 143.4 & 50.6 & 140.0 & $0.361 \pm 0.002$ \\
\hline \multirow[t]{3}{*}{$\mathrm{C} 77-\mathrm{T} 70$} & 1.2 & $n \mathrm{~d}^{\mathrm{b}}$ & 15.8 & 58.4 & $0.270 \pm 0.019$ \\
\hline & 1.1 & $n d^{b}$ & 40.4 & 134.2 & $0.301 \pm 0.013$ \\
\hline & 6.3 & 62.2 & 246.0 & 130.4 & $1.89 \pm 0.018$ \\
\hline C $77-\mathrm{T} 226$ & 6.2 & 67.8 & 146.4 & 101.4 & $1.44 \pm 0.03$ \\
\hline $\mathrm{C} 77-\mathrm{T} 230$ & 9.2 & 50.4 & 236.0 & 264.0 & $0.89 \pm 0.005$ \\
\hline $\mathrm{C} 77-\mathrm{T} 232$ & 1.7 & 72.8 & 113.8 & 103.2 & $1.10 \pm 0.03$ \\
\hline
\end{tabular}

a) The ratio of D-amyl alcohol/isoamyl alcohol is given with the standard deviation estimated from four determinations on the GLC (cf. Materials and Methods, 2.7.).

b) nd $=$ not detected

on enzyme measurements of crude extracts and permeabilized cells and not on a chemical characterization of the pure enzyme. The analogous mutant MAR33 in S. cerevisiae maps in or close to ilvl, which is a well studied locus believed to be the structural gene for threonine deaminase (2).

We found a threonine deaminase inhibition curve with thiaisoleucine quite dissimilar to that obtained with L-isoleucine. A likely interpretation is that thiaisoleucine does not act on threonine deaminase as an isoleucine analogue but binds in some other fashion. On threonine deaminase from Escherichia coli thiaisoleucine seems to act as a threonine analogue, i.e. binding in the active site (6). This may be true in yeast as well. The mechanism of growth inhibition by thiaisoleucine is not known. The primary target of the drug is not necessarily threonine deaminase, since it affects other important enzymes as well (17).

SCHulthess and EtTLINGER (15) have described a mutant of a haploid strain of S. cerevisiae with a feedback resistant $\alpha$-isopropyl malate synthetase which forms three times as much isoamyl alcohol in minimal medium as does the wild type strain. Our data show a similar effect of the altered threonine deaminase activity on the formation of D-amyl alcohol.
Whether the mutants could have any value as brewing strains remains to be seen. It is not known whether the increased synthesis of Damyl alcohol will be found in fermentation of wort. The levels we found of the fusel alcohols in the culture supernatant from the parent strain are much lower than found in beer (8). From a practical point of view, an even more interesting question is whether the level of diacetyl in the beer would be affected by the mutations. We consider this possibility since threonine deaminase may have a direct role in regulating the synthesis of the other enzymes in the pathway (2) and this would in turn determine the amounts of $\alpha$-acetolactate and diacetyl (4).

\section{ACKNOWLEDGEMENTS}

The authors wish to express their gratitude to Dr. Torsten Nilsson-Tillgren, cand. scient. Steen Holmberg, and stud. scient. Bjørn E. Christensen for stimulating discussions, Dipl. Biol. Barbara WiLken for technical assistance and Professor Diter von WeTtSTEIN for support and encouragement. 


\section{REFERENCES}

1. Betz, J. L., L. M. Hereford \& P. T. Magee: Threonine deaminases from Saccharomyces cerevisiae mutationally altered in regulatory properties. Biochemistry 10, 1818-1824 (1971)

2. Bollon, A. P.: Fine structure analysis of a eukaryotic multifunctional gene. Nature 250, 630-634 (1974)

3. Bussey, H. \& H. E. Umbarger: Biosynthesis of branched-chain amino acids in yeast: Regulation of synthesis of the enzymes of isoleucine and valine biosynthesis. J. Bacteriol. 98, 623-628 (1969)

4. Cabane, B., C. Ramos-Jeunehomme, N. Lapage \& C. A. Masschelen: Vicinal diketones - the problem and prospective solutions. Amer. Soc. Brew. Chem. Proc. 1973, pp. 94-99 (1974)

5. Carter, H. E., P. Handler \& D. B. Melville: Azlactones. I. Preparation of benzoyl- $\alpha$-aminocrotonic acid azlactone and the conversion of allothreonine to threonine. J. Biol. Chem. 129 , 359-369 (1939)

6. Cervone, F. \& M. Iaccarino: The action of Omethyl-threonine and thiaisoleucine on threonine deaminase purified from Escherichia coli K-12. FEBS Letters 26, 56-60 (1972)

7. Christensen, B. E., M. C. Kielland-Brandt \& K. ERDAL: Brewing performance of a yeast after prolonged growth on a synthetic medium. Carlsberg Res. Commun. 43, 1-4 (1978)

8. Gjertsen, P. \& A. Schouboe: By-products of fermentation and their influence on beer. Brewers Digest 49 (1), 52-62 (1974)

9. Holmberg, S. \& M. C. Kielland-Brandt: A mutant of Saccharomyces cerevisiae temperature sensitive for flocculation. Influence of oxygen and respiratory deficiency on flocculence. Carlsberg Res. Commun. 43, 37-47 (1978)
10. Magee, P. T. \& L. M. Hereford: Multivalent repression of isoleucine-valine biosynthesis in Saccharomyces cerevisiae. J. Bacteriol. 98, 857862 (1969)

11. McCord, T. J., D. C. Howell, D. L. Tharp \& A. L. DAvIS: 2-amino-3-methylthiobutyric acid, an isoleucine antagonist. J. Med. Chem. 8, 290292 (1965)

12. Netting, A. G. \& C. BarR: Design for an accurate and versatile radio gas chromatograph. Anal. Biochem. 84, 136-146 (1978)

13. Pfleger, R. \& M. von Strandtmann: Über $\alpha$ Acylamino-acrylsäuren, I. Über halogenierte Derivate der $\alpha$-Benzamino-crotonsäure und der $\alpha$-Benzamino-zimtsäure. Chem. Ber. 90, 14551467 (1957)

14. Robichon-Szulmajster, H. De \& P. T. Magee: The regulation of isoleucine-valine biosynthesis in Saccharomyces cerevisiae. 1. Threonine deaminase. Eur. J. Biochem. 3, 492-501 (1968)

15. Schulthess, D. \& L. Ettuinger: Zur Regulation der anabolischen Bildung von Fuselalkoholen. Eur. Brew. Conv., Proc. 16th Congr. Amsterdam, pp. 471-482 (1977)

16. Sternberg, J. C., W. S. Gallaway \& D. T. L. JONES: The mechanisms of response of flame ionization detectors. In: Proceedings of the Instrument Society of America's Third International Symposium on Gas Chromatography, N. Brenner, J. E. Callen \& M. D. Weiss, eds., Academic Press, New York, pp. 231-267 (1962)

17. Szentirmai, A. \& H. E. Umbarger: Isoleucine and valine metabolism of Escherichia coli. XIV. Effect of thiaisoleucine. J. Bacteriol. 95, 1666$1671(1968)$ 